\title{
The climate of the zone of origin of Mediterranean durum wheat (Triticum durum Desf.) landraces affects their agronomic performance
}

\author{
Conxita Royo $\cdot$ Ruyman Nazco $\cdot$ Dolors Villegas
}

Received: 11 November 2013/ Accepted: 31 March 2014/Published online: 7 May 2014

(C) The Author(s) 2014. This article is published with open access at Springerlink.com

\begin{abstract}
The genetic diversity of durum wheat (Triticum durum Desf.) is held by landraces, which are generally considered to be endemic to a particular region to which they are well adapted. To evaluate the effect of climate in the countries of origin on their agronomic performance, 172 durum wheat landraces from 21 Mediterranean countries were grown in northeastern Spain. Average long-term climatic data of the main wheat-growing areas in each country of origin allowed us to identify four climatic zones in the Mediterranean Basin, steadily varying from warm and dry to cool and wet. The phenology, biomass, and yield of landraces were affected by the climatic zone of origin. The climatic zone accounted for 32.8, 28.3 and $14.5 \%$ of variance for days to anthesis, plant height, and grain filling rate, respectively. The number of days to heading and anthesis steadily increased when moving from the warmest and driest zone of origin to the coldest and wettest one. Landraces collected in the warmest and driest zone had a smaller biomass, a lower chlorophyll content in the flag leaf, more fertile tillers, spikes and grains $\mathrm{m}^{-2}$, a lower grain filling rate, lighter grains, and lower yields than those originated in colder and wetter zones. Landraces collected in countries with high solar radiation showed
\end{abstract}

C. Royo $(\bowtie) \cdot$ R. Nazco $\cdot$ D. Villegas

Field Crops Program, Institute for Food and Agricultural Research and Technology (IRTA), Avda. Rovira Roure 191, 25198 Lleida, Spain

e-mail: conxita.royo@irta.es a shorter cycle until anthesis and smaller height and biomass accumulation, while higher temperatures after anthesis resulted in more tillers and spikes. Landraces from countries with high potential evapotranspiration during grain filling had significantly lower grain filling rates and grain weight.

Keywords Biomass - Climatic zones - Grain filling $\cdot$ Phenology $\cdot$ SPAD $\cdot$ Yield
Abbreviations
Tmin Average daily minimum temperature
Tmax Average daily maximum temperature
$\mathrm{Rad}$ Average daily solar radiation
$\mathrm{Rh} \quad$ Average daily relative air humidity
$\mathrm{ET}_{0} \quad$ Potential evapotranspiration
GDD Growing degree-days
CDW Crop dry weight
HI Harvest index
TKW Thousand kernel weight

\section{Introduction}

Wheat is one of the founder crops of Old World agriculture (Zohary and Hopf 2000). Grown on 216.8 million ha in the temperate, Mediterranean-type and subtropical parts of the two hemispheres (FAOSTAT 2011), wheat is currently the crop most 
extensively cultivated in the world. Durum wheat (Triticum durum Desf.) accounts for about $8 \%$ of the global wheat production, and its cultivation is concentrated in latitudes ranging from $55^{\circ} \mathrm{N}$ (Canada) to $40^{\circ} \mathrm{S}$ (Argentina) (Palamarchuk 2005), corresponding mostly to the Mediterranean Basin, the North American Great Plains, India and the former USSR (International Wheat Council 2001).

Cultivated polyploid wheats derive from the wild tetraploid progenitor T. dicoccoides (Körn. ex Asch. et Graebn.) Schweinf. Wheat domestication occurred in the Fertile Crescent between c. 12,000 and c. 10,000 years BP (Tanno and Willcox 2006). Archaeobotanical evidence suggests that the cultivation of wild emmer was taken up independently in the southern and the northern Levant (Peng et al. 2011), spreading west through southern Europe and North Africa (MacKey 2005). North Africa may have been one of the ways by which durum wheat was introduced into the Iberian Peninsula (Moragues et al. 2007). The genetic diversity of the species is currently held by traditional varieties, commonly referred to as landraces, which were originated through agriculture and have probably been grown for several millennia (Zeven 1998). According to Zeven (1998), an autochthonous landrace is regarded 'a variety with a high capacity to tolerate biotic and abiotic stress resulting in high yield stability and an intermediate yield level under a low input agricultural system'. By their own nature, landraces evolve and are mixed through natural and artificial selection processes (Zeven 1998), thus becoming a source of biodiversity. Landraces are generally considered endemic to a particular region to which they are well adapted. The cultivation of local landraces was progressively abandoned from the first decades of the twentieth century, with the advent of new, improved and genetically uniform modern varieties derived from breeding programs. Nowadays, landraces are considered a clue to avoid genetic erosion (Hammer and Teklu 2008), understood as the loss of genetic variability caused by the modernization of agriculture.

It is widely accepted that during domestication and the spread of domesticated wheat from the Fertile Crescent, novel adaptive traits suited to the new environments were selected (Charmet 2011; Peng et al. 2011). Traits that facilitated harvesting and enabled the colonization of new environments were probably primary targets. Among these, larger seeded non-shattering plants (Fuller 2007) or flowering time fit to the prevailing environmental conditions in a given region were presumably critical features in the post-domestication spread of temperate cereals (Cockram et al. 2009). It has been suggested that many other traits, such as plant height, number of spikes and grains per plant, weight of spikes per plant, number of grains per spike and spikelet, and number of spikelets per spike, were also co-selected by ancient farmers (Peng et al. 2011).

The Mediterranean Basin comprises countries between about $27^{\circ}-47^{\circ} \mathrm{N}$ and $10^{\circ} \mathrm{W}-37^{\circ} \mathrm{E}$ shoring on three continents and with a coastline of $46,000 \mathrm{~km}$ (http://www.fao.org/sd/ climagrimed/c_2_02.html). Wheat yield in this region is generally constrained by low and unpredictable seasonal rainfall, as well as by higher temperatures towards the end of the crop cycle. There is a marked climate heterogeneity between zones and years (Xoplaki et al. 2004; Nicault et al. 2008), with periodic episodes of severe drought (Trigo et al. 2010), and the consequent risk of desertification (Greco et al. 2005). In many areas, the rainy season is mostly concentrated between November and March (Trigo et al. 2010), while in others most rain falls during the early spring, thus resulting in moderate stress around anthesis for rainfed wheat. However, in all Mediterranean environments the degree of drought stress increases throughout grain filling (Edmeades et al. 1989). According to Koeppen's climate classification (Leemans and Cramer 1991; http://www.fao. org/sd/EIdirect/climate/EIsp0002.htm), the north and south of the Mediterranean Basin have distinct climates. The predominant climates in the north are types $\mathrm{D}$ (cold) and C (temperate), with average temperatures ranging between -4.5 and $22{ }^{\circ} \mathrm{C}$ and a yearly rainfall between 300 and 1,100 mm. In contrast, in the south of the Basin, climate class B (dry) is prevalent, except in some northern areas of Morocco and Tunisia, which have climate type $\mathrm{C}$ (temperate). The south of the Mediterranean Basin is characterized by an annual potential evapotranspiration that exceeds rainfall and the presence of a dry season during the spring and summer. The mean temperatures are higher than in the north, ranging between 10.5 and $30.5{ }^{\circ} \mathrm{C}$, and annual precipitation between 35 and $725 \mathrm{~mm}$.

In this study we used a set of 172 durum wheat landraces from 21 Mediterranean countries to determine the effect of the prevalent climate in the zones in which they were collected on their agronomic 
performance when grown in a random Mediterranean environment. For this purpose, as country is a political concept, the first step was to identify zones with climatic similarities within the Mediterranean Basin. An additional aim was to identify the climatic variables of the zone of origin that had the largest effect on agronomic traits.

\section{Materials and methods}

Identification of climatic similarities

between countries

Long-term climatic information-including a minimum of 15 years of data-of the 21 countries of origin of the landraces was taken from the CLIMWAT 2.0 FAO database, using the software CROPWAT (www. fao.org). Given its geographic location, Crete was discriminated from Greece, and in this paper it is referred to as a different country. Daily climatic data from 3 to 7 climatic stations per country, located in the main wheatgrowing areas, were averaged. The following data were examined: average daily minimum and maximum temperatures ( $\operatorname{Tmin}$ and $\operatorname{Tmax}{ }^{\circ} \mathrm{C}$ ), average daily relative air humidity $(\mathrm{Rh} \%)$, average daily solar radiation $\left(\operatorname{Rad} \mathrm{MJ} \mathrm{m}^{-2}\right.$ day $^{-1}$ ), average daily rainfall (Rain $\mathrm{mm}$ ), and potential evapotranspiration $\left(\mathrm{ET}_{0} \mathrm{~mm}\right)$, calculated by the Penman-Monteith method. For each country, climatic data were averaged considering two periods: November 20-March 31 and April 1-June 30, assuming that in the Mediterranean Basin the two main growing periods for durum wheat, namely from sowing to anthesis (S-A) and from anthesis to physiological maturity (A-M), are almost coincident with these two periods, respectively. To identify zones of a similar climate within the Mediterranean region, we performed a principal component analysis (PCA) on the correlation matrix calculated with the average long-term climatic data of the 22 countries of origin for S-A and A$\mathrm{M}$, as indicated above.

\section{Field experiments}

A collection of 172 durum wheat landraces and old varieties from 21 Mediterranean countries (Fig. 1) and 20 modern varieties, used as reference, were grown for 3 years in Gimenells $\left(41^{\circ} 40^{\prime} \mathrm{N}, 0^{\circ} 20^{\prime} \mathrm{E}\right.$, and $200 \mathrm{~m}$ a.s.l.), in the province of Lleida (northeastern Spain).
In order to represent the genetic diversity of ancient local durum varieties from the Mediterranean Basin, landraces were selected from a larger collection comprising 231 accessions of distinct origin on the basis of their genetic variability, as determined by 33 SSR-markers (Nazco et al. 2012). Seeds provided by public gene banks (Centro de Recursos Fitogenéticos INIA-Spain, ICARDA Germplasm Bank and USDA Germplasm Bank) were increased in bulk and purified. To ensure a common origin for the seeds of all genotypes seed increasing plots were planted in the same field the year previous to each experiment. The modern set included Spanish, Italian, and French varieties, as well as the U.S. desert durum cultivar Ocotillo.

Experiments consisted of non-replicated plots of $6 \mathrm{~m}^{2}$ (comprising eight 5-m rows, spaced $0.15 \mathrm{~m}$ apart), arranged following a modified augmented design with three checks (cultivars Claudio, Simeto and Vitron). Sowing density was adjusted to 250 germinable seeds $\mathrm{m}^{-2}$. Experiments were conducted under rainfed conditions, but the lack of rain after sowing in 2007 made irrigation necessary in order to achieve seed germination. Climatic data were recorded by a weather station placed in the same field. Soil moisture was monitored in one of the repeated checks from the seedling stage by means of soil probes (model EC-20, $\mathrm{ECH}_{2} \mathrm{O}$ Dielectric Aquameter, Decagon Devices, Inc.) located at 3 depths (0-10, 10-25, and 25-40 cm). Experimental details are shown in Table 1 and Fig. 2. Plots were mechanically harvested at ripening. Weeds and diseases were controlled following standard practices.

Zadoks et al. (1974) growth stages 31 (beginning of jointing), 33 (mid jointing), 45 (booting), 55 (heading), 65 (anthesis) and 87 (physiological maturity) were determined in each plot. Samples of the plants in a $0.5-\mathrm{m}$ long row were pulled up in a central row of each plot at growth stages 21 (tillering), 33, and 65, and a row 1-m long was taken at GS87 (physiological maturity). In the laboratory, the number of plants, tillers, and spikes in each sample were counted, and the aerial portion was weighed after being oven-dried at $70{ }^{\circ} \mathrm{C}$ for $48 \mathrm{~h}$. Crop dry weight $\left(\mathrm{CDW} \mathrm{g} \mathrm{m}{ }^{-2}\right)$ was then calculated as the product of average dry weight per plant and the number of plants $\mathrm{m}^{-2}$ per sample. Fertile tillering was calculated as the quotient between number of spikes and stems $\mathrm{m}^{-2}$. Plots were harvested mechanically at ripening, and grain yield $\left(\mathrm{kg} \mathrm{ha}^{-1}\right)$ 


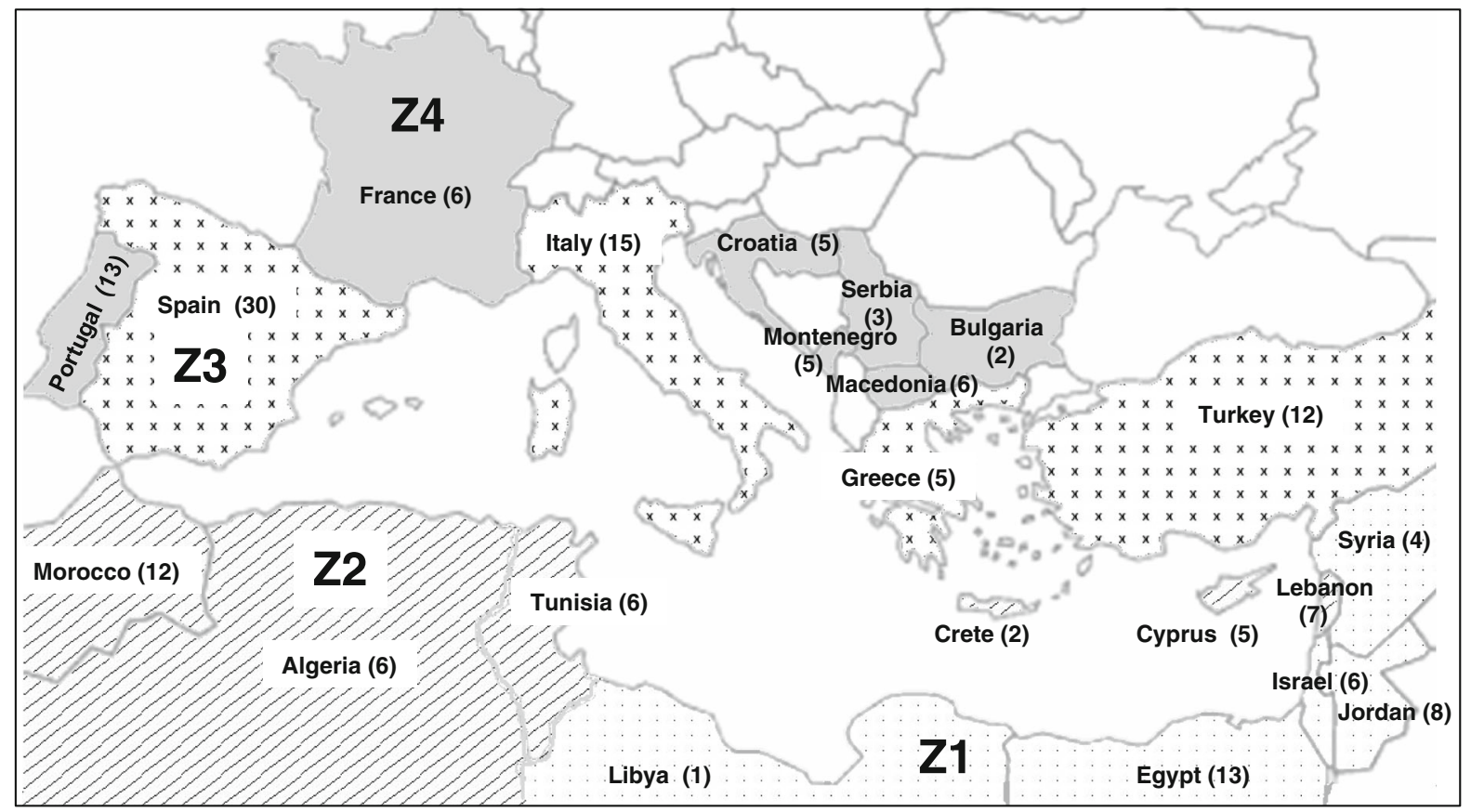

Fig. 1 Countries of origin (Crete was considered a different origin to Greece) of the 172 landraces included in the study. The number of landraces from each territory is shown in parentheses. The four climatic zones that arose from the PCA are also indicated by different drawings

components and to produce the best linear unbiased predictors (BLUPs) for the agronomic data of each accession each year, achieved following the MIXED procedure of the SAS-STAT statistical package (SAS Institute Inc. 2009), which was used for all the analyses. Analyses of variance were conducted to evaluate the variation induced by the climate of the zone origin of the landraces (which were identified from the PCA), on the phenotypic traits when measured in northeastern Spain. A mixed model was used with year and climatic zone as fixed effects and genotype within zone as random effect. Means were compared by the Duncan multiple range test at $P=0.05$. Stepwise regression analyses were conducted with the agronomic traits as dependent variables and the long-term climatic data of the countries origin of landraces as independent variables.

\section{Results}

Identification of climatic zones

In order to identify similarities in climatic conditions between countries, a multivariate analysis was 
Table 1 Details of the experiments conducted in northeastern Spain

${ }^{\text {a }}$ From sowing to maturity

\begin{tabular}{|c|c|c|c|}
\hline Crop season & 2007 & 2008 & 2009 \\
\hline \multicolumn{4}{|l|}{ Soil } \\
\hline Texture & Clay-loamy & Loamy & Sandy-clay-loamy \\
\hline $\mathrm{pH}$ & 8.1 & 8.3 & 8 \\
\hline $\mathrm{P}\left(\mathrm{mg} \mathrm{kg}^{-1}\right)$ & 25 & 27 & 117 \\
\hline $\mathrm{K}\left(\mathrm{mg} \mathrm{kg}^{-1}\right)$ & 163 & 118 & 590 \\
\hline Organic matter (\%) & 2.18 & 2.2 & 3.11 \\
\hline $\mathrm{CE}$ at $25^{\circ} \mathrm{C}\left(\mathrm{dS} \mathrm{m}{ }^{-1}\right)$ & 0.42 & 0.29 & 0.34 \\
\hline \multicolumn{4}{|l|}{ Fertilization $\left(\mathrm{kg} \mathrm{ha}^{-1}\right)$} \\
\hline $\mathrm{N}$ (top dressing) & 32 & 30 & 20 \\
\hline $\mathrm{P}_{2} \mathrm{O}_{5}$ & 110 & 128 & 68 \\
\hline $\mathrm{K}_{2} \mathrm{O}$ & 183 & 213 & 113 \\
\hline \multicolumn{4}{|l|}{ Enviromental $^{\mathrm{a}}$} \\
\hline Radiation (MJ m ${ }^{-2} \mathrm{~d}^{-1}$ ) & 12.72 & 13.87 & 13.54 \\
\hline Average daily Rh (\%) & 53.36 & 73.42 & 50.79 \\
\hline Accumulated $\mathrm{ET}_{0}(\mathrm{~mm})$ & 386 & 440 & 396 \\
\hline Sowing date & 21-Nov-06 & 20-Nov-07 & 20-Nov-08 \\
\hline Harvest date & 2-Jul-07 & 2-Jul-08 & 15-Jul-09 \\
\hline
\end{tabular}

conducted with the long-term climatic data of the 22 countries. The first two axes of the PCA, shown in Fig. 3, accounted for $80.7 \%$ of the total variance (axis 1, $69.4 \%$; axis 2, $11.3 \%$ ). The Eigenvectors of the various components, shown in Fig. 3a, reflect the extent to which each variable weights the two components. Principal component 1 (PC1) was positively related to minimum and maximum temperatures, radiation, and $\mathrm{ET}_{0}$ along the growing season, and negatively associated with the rainfall during grain filling and relative air humidity. Increases in PC2 were related mostly to rainfall and relative humidity from sowing to anthesis in the positive and negative directions, respectively. The angles between vectors indicated strong positive correlations between solar radiation, temperatures and $\mathrm{ET}_{0}$. On the other hand, those between vectors representing rainfall or relative humidity and average maximum temperature during grain filling, both close to $180^{\circ}$, indicated negative relationships.

The points representing the countries of origin of landraces, shown in Fig. 3b, were grouped in four clusters along PC1. Southeastern Mediterranean countries were located in the bottom right part of the figure, indicating a climate characterized by high maximum temperatures, radiation and $\mathrm{ET}_{0}$, and water scarcity during grain filling. The northern Balkan countries,
France, and Portugal, with opposing climatic characteristics, were placed on the opposite side of the figure. The intermediate position between these two groups was occupied by another two clusters: one formed by the Maghreb countries plus Crete, Cyprus, and Lebanon, and the other including Turkey, Greece, Italy, and Spain. The location of Lebanon and Montenegro in the upper part of their corresponding clusters indicates that winters are particularly wet in these countries. The average values of the climatic variables of the zones represented by the clusters confirm decreasing temperatures, radiation, and $\mathrm{ET}_{0}$ when moving from $\mathrm{Z} 1$ to $\mathrm{Z} 4$ but increasing rainfall, mostly during the spring (Table 2).

Field testing environment

The pattern of increasing temperatures during the spring and the uneven distribution of rainfalls recorded in the experimental fields during the 3 years of field testing correctly represent a typical Mediterranean environment (Fig. 2). The lowest temperatures were reached in December and January, and temperatures drastically increased during the spring, reaching a maximum of almost $30^{\circ} \mathrm{C}$ in June, coinciding with the last phases of grain filling. Water input was 192 , 
289 , and $190 \mathrm{~mm}$ in the growing seasons of 2007, 2008 and 2009, respectively, and in 2009 the soil moisture during the spring reached the lowest level of the 3 years (Fig. 2).

Effect of the climatic zone of origin on the agronomic performance of landraces

\section{Phenology}

The ANOVA for phenological data showed that the year, climatic zone, and genotype significantly affected the phenologic development of the landraces (Table 3). The environmental conditions of the year accounted for most of the variability in total cycle length and grain filling duration. The percentage of the sum of squares explained by the climatic zone origin of the landraces was low for the time elapsed from sowing to early growth stages, but increased until anthesis, when it accounted for about $33 \%$ of total variance. The mean values of the duration of the different phases of the crop cycle for the four climatic zones revealed that the number of days from sowing to the main growth stages consistently increased from Z1 to $\mathrm{Z} 4$, the opposite being true for the duration of the grain filling period (Table 4). The phenology of modern varieties was closer to that of landraces from Z1 (southeastern Mediterranean countries) than to that recorded in landraces belonging to the remaining climatic zones.

\section{Biomass and associated traits}

The percentage of variability for CDW at different growth stages from tillering to maturity explained by the climatic zone of origin was much lower than that obtained for phenological development; it was greatest at maturity, but even so, it accounted only for only about $8 \%$ of total variation (Table 3 ). The comparison of $\mathrm{CDW}$ values of the landraces indicated that, except at jointing, when differences were not statistically significant, genotypes from $\mathrm{Z} 1$ had less biomass than those of the other zones (Table 4). Although CDW at jointing and anthesis did not differ significantly between Z2, Z3 and Z4, biomass tended to increase when moving from Z1 to Z4. Although modern varieties had lower $\mathrm{CDW}$ values than the
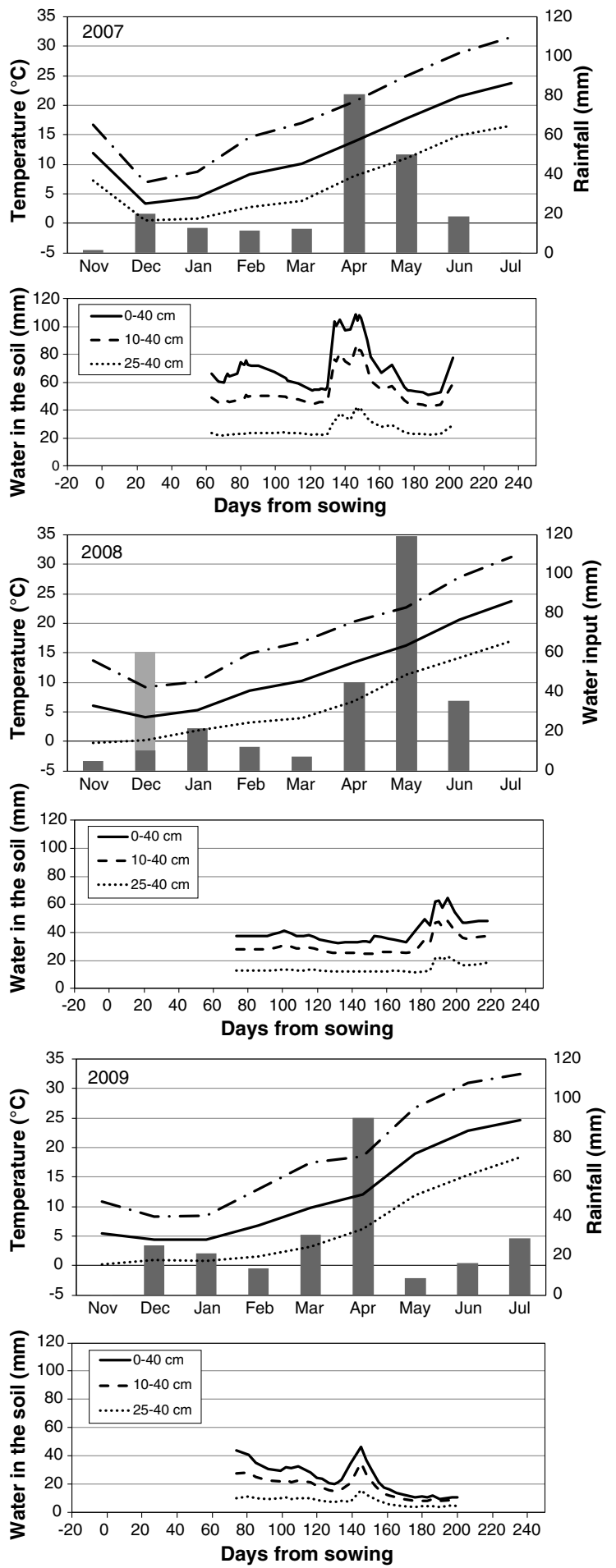

Fig. 2 Monthly water input and maximum (dashed line), mean (solid line) and minimum (dotted line) temperatures during the growth cycle of each crop season. The lowest figures indicate the water soil content at three depths $(0-40,10-40$ and $25-40 \mathrm{~cm})$ for each year 


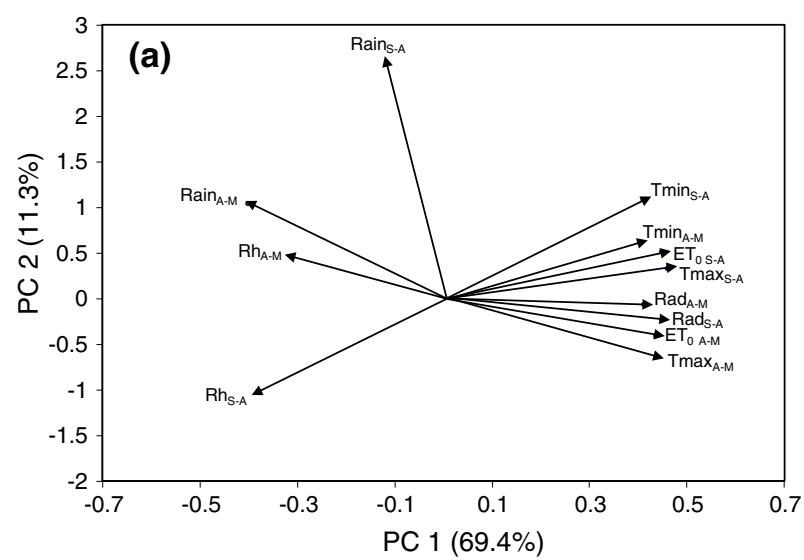

Fig. 3 Biplot of the first two axes of the principal component analysis summarizing the relationships between long-term climatic variables of the countries origin of the landraces. a Eigenvalues of the correlation matrix symbolized as vectors representing climatic variables for the period sowing-anthesis (subscript $S-A$ comprising November 20-March 31), and anthesis-physiological maturity (subscript $A-M$ comprising

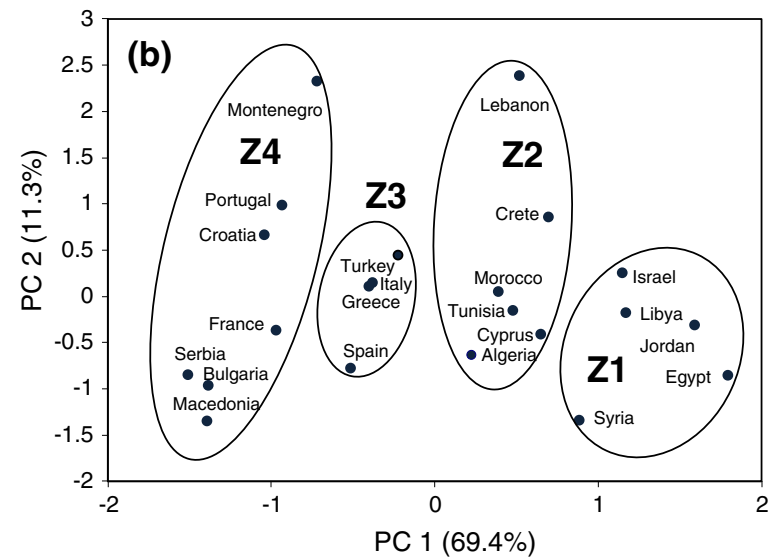

April 1-June 30). Tmin average minimum daily temperature, Tmax average maximum daily temperature, Rain average daily rainfall, $E T_{O}$ accumulated potential evapotranspiration, Rad average daily solar radiation, $R h$ average daily relative humidity. b Plot of the points corresponding to the 21 countries and Crete

Table 2 Average long-term climatic variables of the four Mediterranean climatic zones that arose from the PCA

\begin{tabular}{|c|c|c|c|c|c|c|c|}
\hline Climatic zone & $\operatorname{Tmin}\left({ }^{\circ} \mathrm{C}\right)$ & $\operatorname{Tmax}\left({ }^{\circ} \mathrm{C}\right)$ & Tmean $\left({ }^{\circ} \mathrm{C}\right)$ & $\operatorname{Rad}\left(\mathrm{MJ} \mathrm{m}^{-2} \mathrm{~d}^{-1}\right)$ & $\mathrm{Rh}(\%)$ & $\mathrm{ET}_{0}(\mathrm{~mm})$ & Rain (mm) \\
\hline \multicolumn{8}{|c|}{ Sowing-anthesis } \\
\hline $\mathrm{Z1}$ & $7.8^{\mathrm{a}}$ & $19.0^{\mathrm{a}}$ & $13.4^{\mathrm{a}}$ & $12.7^{\mathrm{a}}$ & $67.1^{\mathrm{c}}$ & $299^{\mathrm{a}}$ & $188^{\mathrm{a}}$ \\
\hline $\mathrm{Z} 2$ & $8.2^{\mathrm{a}}$ & $17.6^{\mathrm{a}}$ & $12.9^{\mathrm{a}}$ & $10.8^{\mathrm{b}}$ & $70.5^{\mathrm{bc}}$ & $255^{\mathrm{a}}$ & $318^{\mathrm{a}}$ \\
\hline $\mathrm{Z3}$ & $5.3^{\mathrm{a}}$ & $13.6^{\mathrm{b}}$ & $9.5^{\mathrm{b}}$ & $8.2^{\mathrm{c}}$ & $74.2^{\mathrm{ab}}$ & $178^{\mathrm{b}}$ & $305^{\mathrm{a}}$ \\
\hline $\mathrm{Z} 4$ & $2.0^{\mathrm{b}}$ & $9.8^{\mathrm{c}}$ & $5.9^{\mathrm{c}}$ & $6.9^{\mathrm{c}}$ & $77.2^{\mathrm{a}}$ & $134^{\mathrm{b}}$ & $390^{\mathrm{a}}$ \\
\hline \multicolumn{8}{|c|}{ Anthesis-maturity } \\
\hline $\mathrm{Z1}$ & $15.1^{\mathrm{a}}$ & $29.3^{\mathrm{a}}$ & $22.2^{\mathrm{a}}$ & $23.7^{\mathrm{a}}$ & $51.0^{\mathrm{b}}$ & $531^{\mathrm{a}}$ & $20.0^{\mathrm{c}}$ \\
\hline $\mathrm{Z} 2$ & $14.0^{\mathrm{ab}}$ & $25.3^{\mathrm{b}}$ & $19.7^{\mathrm{b}}$ & $22.4^{\mathrm{a}}$ & $63.0^{\mathrm{a}}$ & $401^{\mathrm{b}}$ & $60.4^{\mathrm{bc}}$ \\
\hline $\mathrm{Z3}$ & $12.6^{\mathrm{b}}$ & $23.5^{\mathrm{c}}$ & $18.0^{\mathrm{c}}$ & $19.5^{\mathrm{b}}$ & $63.2^{\mathrm{a}}$ & $341^{\mathrm{c}}$ & $109^{\mathrm{b}}$ \\
\hline Z4 & $10.7^{\mathrm{c}}$ & $21.6^{\mathrm{d}}$ & $16.1^{\mathrm{d}}$ & $18.8^{\mathrm{b}}$ & $65.0^{\mathrm{a}}$ & $309^{c}$ & $210^{\mathrm{a}}$ \\
\hline
\end{tabular}

Sowing-anthesis and anthesis-maturity were considered to be the periods elapsed from November 20 to March 31 , and from April 1 to June 30 , respectively

Tmin average minimum daily temperature, Tmax average maximum daily temperature, Tmean average mean daily temperature, Rad average daily solar radiation, $R h$ average daily relative humidity, $E T_{O}$ accumulated potential evapotranspiration, Rain average daily rainfall

Means within columns and periods with different letters are significantly different at $P=0.05$

landraces in the four growth stages, their values were closer to those of landraces from $\mathrm{Z} 1$ than to those recorded in landraces from other climatic zones.

The climatic zone of origin explained $28.3 \%$ of the variability observed for plant height (Table 3 ). Landraces from $Z 1$ were $14 \mathrm{~cm}$ shorter than those from $Z 2$, which in turn were $6 \mathrm{~cm}$ shorter that those of $\mathrm{Z} 3$. Although landraces from $\mathrm{Z} 4$ were $4 \mathrm{~cm}$ taller than those of Z3, these differences were not statistically significant (Table 4). As expected, modern varieties were shorter than the landraces. Variability in the HI was explained mostly by year variations and, to a lower extent, by genotypic differences, while the climatic zone did not have any effect. Chlorophyll content, determined in SPAD units 1 week after anthesis, differed between landraces from distinct 
Table 3 Percentage of the sum of squares of the ANOVA for phenology, biomass, yield and associated traits for 172 durum wheat landraces from four Mediterranean climatic zones and evaluated during 3 years in north-eastern Spain

\begin{tabular}{|c|c|c|c|}
\hline Source of variation & Years & $\begin{array}{l}\text { Climatic } \\
\text { zone }\end{array}$ & $\begin{array}{l}\text { Genotype } \\
\text { (zone) }\end{array}$ \\
\hline \multicolumn{4}{|l|}{ Phenology } \\
\hline \multicolumn{4}{|l|}{ Days from sowing to } \\
\hline Beginning of jointing & $16.2 * * *$ & $9.2 * * *$ & $44.7 * * *$ \\
\hline Mid jointing & $58.8 * * *$ & $6.2 * * *$ & $19.6 * * *$ \\
\hline Booting & $10.7 * * *$ & $26.4 * * *$ & $52.9 * * *$ \\
\hline Heading & $2.5 * * *$ & $30.9 * * *$ & $60.0 * * *$ \\
\hline Anthesis & $1.1 * * *$ & $32.8 * * *$ & $54.4 * * *$ \\
\hline Maturity & $87.0 * * *$ & $3.1 * * *$ & $6.5 * * *$ \\
\hline Days anthesis-maturity & $90.9 * * *$ & $1.3 * * *$ & $4.8 * * *$ \\
\hline \multicolumn{4}{|l|}{ Biomass and associated traits } \\
\hline \multicolumn{4}{|l|}{ Crop dry weight at } \\
\hline Tillering & $30.4 * * *$ & $1.8 * *$ & 23.0 \\
\hline Jointing & $93.6 * * *$ & 0.02 & 2.2 \\
\hline Anthesis & $29.9 * * *$ & $7.7 * * *$ & $26.3 * *$ \\
\hline Maturity & $5.3 * * *$ & $7.9 * * *$ & $38.1 * * *$ \\
\hline Plant height & $4.4 * * *$ & $28.3 * * *$ & $53.4 * * *$ \\
\hline Harvest index & $77.7 * * *$ & 0.5 & $12.5 * * *$ \\
\hline $\begin{array}{l}\text { SPAD } 1 \text { week after } \\
\text { anthesis }\end{array}$ & $42.1 * * *$ & $2.9 * *$ & $28.6^{* * *}$ \\
\hline \multicolumn{4}{|l|}{ Yield and yield components } \\
\hline Number of tillers $\mathrm{m}^{-2}$ & $19.4 * * *$ & $3.2 *$ & $47.0 * * *$ \\
\hline Fertile tillering & $77.0 * * *$ & $1.0 * * *$ & 7.3 \\
\hline Number of spikes $\mathrm{m}^{-2}$ & $37.1 * * *$ & $3.7 * * *$ & $35.6 * * *$ \\
\hline Number of grains spike ${ }^{-1}$ & $7.7 * * *$ & 0.5 & $46.1 * * *$ \\
\hline Number of grains $\mathrm{m}^{-2}$ & $35.3 * * *$ & $6.1 * * *$ & $39.3 * * *$ \\
\hline Grain filling rate & $15.9 * * *$ & $14.5 * * *$ & $45.5 * * *$ \\
\hline Thousand kernel weight & $65.6 * * *$ & $5.7 * * *$ & $20.8 * * *$ \\
\hline Yield & $65.6 * * *$ & $1.0 * *$ & $13.3 *$ \\
\hline
\end{tabular}

* $P<0.05 ; * * P<0.01$;*** $P<0.001$

climatic zones (Table 3), and this difference was caused by the lowest SPAD values of the landraces from Z1 (Table 4). Modern varieties had the largest HI and flag leaf chlorophyll content.

Yield and yield components

The year effect accounted for most of the variation in fertile tillering, yield, and TKW. The climatic zone origin significantly affected yield and all the yield components studied, with the exception of the number of grains per spike (Table 3). Although the effect of the zone of origin was significant, the percentage of variability accounted for was in general very low, except for the mean rate of grain filling. The significance of the zone effect for yield and associated traits was due mostly to the differences between landraces from $\mathrm{Z} 1$ and those of the remaining zones (Table 4). Yield and kernel weight were the lowest in genotypes from the southeastern countries of the Mediterranean Basin (Z1); however, the number of tillers, spikes and grains per unit area were greatest in the landraces from this zone. Fertile tillering was lower in genotypes from $\mathrm{Z} 3$ and $\mathrm{Z} 4$ than in those of Z1. When compared with the landraces, modern varieties had intermediate values for the number of tillers and spikes per unit area, more grains per spike and per unit area, superior fertile tillering and yield, and a similar mean grain filling rate to that of the landraces from Z1 (Table 4).

\section{Identification of climatic traits in the country of origin that most affect the agronomic performance of landraces}

The climatic variables of the countries origin that most affected the agronomic performance of the landraces were identified through regression analysis, in which agronomic traits were considered as dependent variables and the long-term climatic variables as independent ones. Average daily solar radiation from sowing to anthesis was the only variable entered in the model that explained differences in the length of this period, exerting a negative effect and accounting for $64 \%$ of its variation (Table 5). Average daily solar radiation from sowing to anthesis also explained a large portion of the variation in crop biomass, while average daily solar radiation from anthesis to maturity was the most significant climatic variable negatively affecting total cycle length and plant height (Table 5). On the other hand, $64 \%$ of the duration of the grain filling period was explained by the combination of accumulated $\mathrm{ET}_{0}$ and average daily relative humidity after anthesis. The effect of long-term climatic variables was low for the $\mathrm{HI}$ and chlorophyll content in the flag leaf 1 week after anthesis, and none of these variables significantly accounted for variations in fertile tillering or the number of grains per spike. The minimum temperature during grain filling was the most important climatic variable explaining variations in the number of tillers and spikes per unit area, while 
Table 4 Mean values of phenology, biomass, yield and associated traits of 172 durum wheat landraces from four Mediterranean climatic zones and evaluated during 3 years in northeastern Spain
Mean values of 20 modern varieties are included for reference

Means within rows with different letters are significantly different at $P=0.05$

\begin{tabular}{|c|c|c|c|c|c|}
\hline & $\mathrm{Z1}$ & $\mathrm{Z} 2$ & $\mathrm{Z3}$ & $\mathrm{Z} 4$ & $\begin{array}{l}\text { Modern } \\
\text { varieties }\end{array}$ \\
\hline \multicolumn{6}{|l|}{ Phenology } \\
\hline \multicolumn{6}{|l|}{ Days from sowing to } \\
\hline Beginning of jointing & $123^{\mathrm{b}}$ & $124^{\mathrm{b}}$ & $126^{\mathrm{a}}$ & $126^{\mathrm{a}}$ & 124 \\
\hline Mid jointing & $139^{\mathrm{d}}$ & $140^{\mathrm{c}}$ & $141^{\mathrm{b}}$ & $142^{\mathrm{a}}$ & 138 \\
\hline Booting & $147^{\mathrm{d}}$ & $149^{\mathrm{c}}$ & $152^{\mathrm{b}}$ & $153^{\mathrm{a}}$ & 145 \\
\hline Heading & $154^{\mathrm{d}}$ & $157^{\mathrm{c}}$ & $159^{\mathrm{b}}$ & $161^{\mathrm{a}}$ & 151 \\
\hline Anthesis & $161^{\mathrm{d}}$ & $163^{\mathrm{c}}$ & $165^{\mathrm{b}}$ & $167^{\mathrm{a}}$ & 159 \\
\hline Maturity & $195^{\mathrm{c}}$ & $197^{\mathrm{b}}$ & $198^{\mathrm{a}}$ & $199^{\mathrm{a}}$ & 195 \\
\hline Days anthesis-maturity & $34^{\mathrm{a}}$ & $34^{\mathrm{a}}$ & $32^{\mathrm{b}}$ & $32^{\mathrm{c}}$ & 36 \\
\hline \multicolumn{6}{|l|}{ Biomass and associated traits } \\
\hline \multicolumn{6}{|l|}{ Crop dry weight $\left(\mathrm{g} \mathrm{m}^{-2}\right)$ at } \\
\hline Tillering & $68.6^{\mathrm{b}}$ & $75.7^{\mathrm{a}}$ & $72.8^{\mathrm{a}}$ & $73.6^{\mathrm{a}}$ & 63.2 \\
\hline Jointing & $406^{\mathrm{a}}$ & $406^{\mathrm{a}}$ & $408^{\mathrm{a}}$ & $411^{\mathrm{a}}$ & 399 \\
\hline Anthesis & $838^{\mathrm{b}}$ & $1,001^{\mathrm{a}}$ & $1,039^{\mathrm{a}}$ & $1,054^{\mathrm{a}}$ & 805 \\
\hline Maturity & $1,100^{\mathrm{c}}$ & $1,185^{\mathrm{b}}$ & $1,210^{\mathrm{b}}$ & $1,274^{\mathrm{a}}$ & 1,076 \\
\hline Plant height $(\mathrm{cm})$ & $94^{\mathrm{c}}$ & $108^{\mathrm{b}}$ & $114^{\mathrm{a}}$ & $118^{\mathrm{a}}$ & 75 \\
\hline Harvest index & $0.38^{\mathrm{a}}$ & $0.37^{\mathrm{a}}$ & $0.36^{\mathrm{a}}$ & $0.36^{\mathrm{a}}$ & 0.42 \\
\hline SPAD 1 week after anthesis & $50.2^{\mathrm{b}}$ & $51.7^{\mathrm{a}}$ & $51.5^{\mathrm{a}}$ & $51.3^{\mathrm{a}}$ & 53.9 \\
\hline \multicolumn{6}{|l|}{ Yield and yield components } \\
\hline Number of tillers $\mathrm{m}^{-2}$ & $369^{\mathrm{a}}$ & $332^{\mathrm{b}}$ & $336^{\mathrm{b}}$ & $337^{\mathrm{b}}$ & 341 \\
\hline Fertile tillering $(\%)$ & $0.76^{\mathrm{a}}$ & $0.75^{\mathrm{ab}}$ & $0.73^{\mathrm{c}}$ & $0.74^{\mathrm{bc}}$ & 0.77 \\
\hline Number of spikes $\mathrm{m}^{-2}$ & $406^{\mathrm{a}}$ & $370^{\mathrm{b}}$ & $365^{\mathrm{b}}$ & $369^{\mathrm{b}}$ & 389 \\
\hline Number of grains spike ${ }^{-1}$ & $21^{\mathrm{a}}$ & $21^{\mathrm{a}}$ & $21^{\mathrm{a}}$ & $20^{\mathrm{a}}$ & 22 \\
\hline Number of grains $\mathrm{m}^{-2}$ & $8,157^{\mathrm{a}}$ & $7,433^{\mathrm{b}}$ & $7,386^{\mathrm{b}}$ & $7,285^{\mathrm{b}}$ & 8,570 \\
\hline Grain filling rate $\left(\mathrm{mg} \mathrm{GDD}^{-1}\right)$ & $0.065^{\mathrm{b}}$ & $0.074^{\mathrm{a}}$ & $0.075^{\mathrm{a}}$ & $0.077^{\mathrm{a}}$ & 0.065 \\
\hline Thousand kernel weight (g) & $42.8^{\mathrm{b}}$ & $48.9^{\mathrm{a}}$ & $48.9^{\mathrm{a}}$ & $49.4^{\mathrm{a}}$ & 46.4 \\
\hline Yield $\left(\mathrm{kg} \mathrm{ha}^{-1}\right)$ & $3,411^{\mathrm{b}}$ & $3,525^{\mathrm{a}}$ & $3,514^{\mathrm{a}}$ & $3,509^{\mathrm{a}}$ & 3,800 \\
\hline
\end{tabular}

rain during grain filling negatively affected the number of grains $\mathrm{m}^{-2}$ (Table 5). Landraces from countries with high $\mathrm{ET}_{0}$ during grain filling had significantly lower grain filling rates and grain weight. Finally, accumulated $\mathrm{ET}_{0}$ from sowing to anthesis negatively affected grain yield and explained $23 \%$ of yield variations.

\section{Discussion}

The multivariate analysis of the long-term climatic data of the countries origin of the landraces showed that most of the information contained in the climatic data could be summarized by projecting the points in the plane determined by the first two axes. The first axis, which explained about $70 \%$ of total variation, allowed the identification of four climatic zones based on two opposite groups of climatic traits. Climatic variables related to high temperatures, radiation, and $\mathrm{ET}_{0}$ were placed to the right of $\mathrm{PC} 1$, while the eigenvectors representing rainfall-mostly during grain filling - and relative humidity were on the left part of the figure. The two clusters located on the positive side of PC1 grouped southern Mediterranean countries, characterized by high temperatures, radiation, and $\mathrm{ET}_{0}$, and very dry climates. Northern Mediterranean countries were located on the negative side of PC1, implying cooler and wetter climates. On this side, the Balkan countries, together with France and Portugal - the latter probably due to the Atlantic influence-had the most extreme conditions, while a strip joining countries with coastlines on the northern shore of the Mediterranean were located close to the 
Table 5 Regression equations for the relationships between agronomic traits $(Y)$ as dependent variables and long-term climatic variables of the zones origin of 172 durum wheat Mediterranean landraces as independent variables

\begin{tabular}{|c|c|c|c|c|c|}
\hline Trait & Regression equation & & Partial $R^{2}$ & Model $R^{2}$ & $P<$ \\
\hline Days sowing-anthesis & $Y=174-0.99 \operatorname{Rad}_{\mathrm{S}-\mathrm{A}}$ & & & 0.64 & 0.0001 \\
\hline Days sowing-maturity & $Y=211-0.65 \operatorname{Rad}_{\mathrm{A}-\mathrm{M}}$ & & & 0.58 & 0.0001 \\
\hline \multirow[t]{2}{*}{ Days anthesis-maturity } & $Y=20.5+0.017 \mathrm{ET}_{0 \mathrm{~A}-\mathrm{M}}+0.091 \mathrm{Rh}_{\mathrm{A}-\mathrm{M}}$ & $\mathrm{ET}_{0 \mathrm{~A}-\mathrm{M}}$ & 0.55 & 0.55 & 0.0001 \\
\hline & & $\mathrm{Rh}_{\mathrm{A}-\mathrm{M}}$ & 0.09 & 0.64 & 0.0458 \\
\hline $\mathrm{CDW}$ at anthesis & $Y=1,281-31.61 \operatorname{Rad}_{\mathrm{S}-\mathrm{A}}$ & & & 0.42 & 0.0012 \\
\hline CDW at maturity & $Y=1,458-26.41 \operatorname{Rad}_{\mathrm{S}-\mathrm{A}}$ & & & 0.63 & 0.0001 \\
\hline Plant height & $Y=178-3.32 \operatorname{Rad}_{\mathrm{A}-\mathrm{M}}$ & & & 0.43 & 0.0009 \\
\hline Harvest index & $Y=0.402-0.0006 \mathrm{Rh}_{\mathrm{A}-\mathrm{M}}$ & & & 0.18 & 0.047 \\
\hline SPAD 1 week after anthesis & $Y=52.26-0.170 \mathrm{Tmin}_{\mathrm{S}-\mathrm{A}}$ & & & 0.18 & 0.0463 \\
\hline Number of tillers $\mathrm{m}^{-2}$ & $Y=26.11+0.95 \mathrm{Tmin}_{\mathrm{A}-\mathrm{M}}$ & & & 0.20 & 0.0366 \\
\hline Fertile tillering & & & & - & \\
\hline Number of spikes $\mathrm{m}^{-2}$ & $Y=303+6.45 \operatorname{Tmin}_{\mathrm{A}-\mathrm{M}}$ & & & 0.27 & 0.0138 \\
\hline Number of grains spike ${ }^{-1}$ & & & & - & \\
\hline Number of grains $\mathrm{m}^{-2}$ & $Y=7,861-2.76$ Rain $_{\mathrm{A}-\mathrm{M}}$ & & & 0.31 & 0.0074 \\
\hline Grain filling rate & $Y=100-0.048 \mathrm{ET}_{0 \mathrm{~A}-\mathrm{M}}$ & & & 0.51 & 0.0002 \\
\hline Thousand kernel weight & $Y=55.54-0.020 \mathrm{ET}_{0 \mathrm{~A}-\mathrm{M}}$ & & & 0.38 & 0.0023 \\
\hline Yield & $Y=3,621-0.54 \mathrm{ET}_{0 \mathrm{~S}-\mathrm{A}}$ & & & 0.23 & 0.0243 \\
\hline
\end{tabular}

$\mathrm{N}=22$ (21 countries + Crete). Only variables that met the 0.05 significance level entered the models

Tmin average minimum daily temperature, Tmax average maximum daily temperature, Rad average daily solar radiation, $R h$ average daily relative humidity, $E T_{O}$ accumulated potential evapotranspiration, Rain average daily rainfall, $C D W$ crop dry weight

origin of the axis. The results of the PCA classified the main wheat-growing areas within the Mediterranean Basin into four climatic zones that followed a consistent trend, from warm and dry to cool and wet environments when moving from the south (Z1) to the north (Z4). Long-term climatic data revealed that the two sides of the Mediterranean Basin were clearly separated, in close agreement with the Koeppen's climatic classification (Leemans and Cramer 1991).

The meteorological conditions of the 3 years of field experiments conducted in northeastern Spain reflected the typical variations of Mediterranean climates between and within cropping seasons. The temperature patterns over the 3 years were more similar than the distribution of rainfall. As a result, broad differences between years were detected in soil water content during the whole cycle length, thus possibly contributing to the wide year effect found for some agronomic traits such as fertile tillering, HI, kernel weight and yield. Indeed, in a previous study the erratic distribution of rainfall explained as much as $75 \%$ of the variation in wheat yield in the Mediterranean region (Blum and Pnuel 1990).
The 172 landraces used in this study showed great variability in agronomic performance. Previous research conducted with the same collection revealed that it properly represents the diversity of durum wheat landraces in the Mediterranean Basin for yield, quality attributes (Nazco et al. 2012), glutenin alleles (Nazco et al. 2013), and allelic combinations at Glu-1/Glu-3 loci (Nazco et al. 2014). Our results revealed a significant effect of the climatic zone origin on the number of days the landraces needed to reach the main growth stages. The varieties originated in Z4 (the coldest and wettest zone) required from 3 to 7 more days from sowing to the different growth stages than those originated in $\mathrm{Z} 1$ (the warmest and driest zone). The period elapsed from sowing to anthesis increased by 2 days when moving from one zone to the other in the direction $\mathrm{Z} 1$ to $\mathrm{Z} 4$, and this cycle enlargement from Z1-Z2-Z3-Z4 was consistent at all growth stages. Solar radiation was the climatic trait of zone of origin that most affected the cycle length of landraces. Consequently, the higher radiation in the southern zones resulted in landraces with a shorter cycle. The observed cycle lengthening of the landraces from cool 
areas in comparison with those of warm ones is consistent with the reported enhanced crop growth period induced in wheat by lower mean temperatures during the growing period (Chakrabarti et al. 2011). A previous study showed that drought stress and high temperature in the collecting site of durum wheat landraces affected drought tolerance and reduced time to heading thus affecting yield potential (Annicchiarico et al. 1995). Early heading is one of the most common physiological mechanisms of drought escape. In well watered environments yield potential increases with growth duration, but in drought stressed environments the advantage of late flowering may turn into a disadvantage (Blum 2011). As drought stress in this study was not severe during grain filling, early heading did not represent a constitutive advantage in terms of grain yield.

The early anthesis of landraces from southern zones (Z1 and Z2) may have caused the duration of grain filling to last 2 days more than that of landraces from northern zones (Z3 and Z4). This observation is consistent with the reported longer post-anthesis duration of early-anthesis wheat cultivars (Tewolde et al. 2006). The large effect of the environmental conditions on grain filling duration observed in this study and reported by other authors (Wiegand and Cuellar 1981; Santiveri et al. 2002) could explain why the 6 days of delay to the date of anthesis of landraces from $\mathrm{Z} 4$ compared with those of $\mathrm{Z} 1$ were reduced to 4 days of difference in the number of days at maturity. Accumulated $\mathrm{ET}_{0}$ and relative humidity from anthesis to maturity in the climatic zone of origin were the most important traits in explaining grain filling duration, with both variables accounting for $64 \%$ of variation in the length of this period.

As expected, the percentage of variability explained by the climatic zone origin was lower for biomass, yield, and associated traits of the landraces than for phenological development. However, except for biomass at jointing and the HI, which largely depended on the year, and the number of grains per spike, which had an important genetic control, all the remaining traits studied were significantly affected by the climatic zone of origin. Biomass at anthesis of landraces from the southeastern Mediterranean Basin (Z1), with high temperatures and solar radiation, and low rainfall, particularly during grain filling, was lower than that of the landraces from the colder regions within the area, in which solar radiation was lower and rain more abundant. The lowest biomass of landraces from Z1 may be interpreted in terms of the existing genetic association between growth duration and leaf number and leaf size, and is in agreement with the reported negative effects of water scarcity on durum wheat growth in the Mediterranean Basin (Villegas et al. 2001; Royo et al. 2004). The largest and most negative effect of a climatic trait in the country origin on the biomass accumulation of landraces both at anthesis and maturity was that of solar radiation, one of the critical climatic determinants of wheat production. The conceptual model proposed by Hay (1999) considers yield as a direct function of incoming radiation, with biomass being determined from it, the fraction intercepted by the crop, and the radiation-use-efficiency (Araus et al. 2002). Accordingly, the greater the radiation available the higher the biomass produced. Nevertheless, this theoretical model is valid only when temperature and water supply are not limiting (Richards 2000), which is not the case in Mediterranean environments. The negative relationship found between radiation in the country of origin and biomass accumulation may reflect an adaptive mechanism. Thus, landraces originated in areas with high solar radiation-also with high temperatures and $\mathrm{ET}_{0}$ as revealed by the position of the eigenvectors in the PCA-would produce less biomass as an adaptive mechanism to reduce radiation interception by crop canopy and to limit photoinhibition.

The climatic zone origin explained $28.3 \%$ of the variation in plant height of landraces. The trend of increasing plant height when moving from $\mathrm{Z} 1$ to $\mathrm{Z} 4$ could be partially attributed to the inhibition of this trait caused by a limited water supply (Xianshan et al. 2010), and, according to our results, mostly by a high solar radiation from anthesis to maturity. This finding is consistent with the observation that landraces from drier and warmer areas were shorter than those from wetter and colder regions. However, the biomass and plant height of landraces from Z3 and Z4 may have also been enhanced during wheat expansion, as it has been proposed that ancient farmers selected tall mutants because of their higher biomass and yield potential (Peng et al. 2011).

Despite being significant as a result of the low SPAD values of landraces from climatic $\mathrm{Z} 1$, the effect of long-term climatic variables on the flag leaf chlorophyll content 1 week after anthesis was small 
(2.9\%). Low leaf chlorophyll content is a photoprotection mechanism in cereals, characteristic of landraces adapted to semi-arid environments (Havaux and Tardy 1999), which is in accordance with the results obtained in this study. In addition, our results indicate that landraces from areas with high minimum temperatures before anthesis tend to have a lower chlorophyll content in the flag leaf 1 week after anthesis; however, this climatic variable accounted for only $18 \%$ of variation in SPAD values, which depended mostly on yearly variations and were under significant genetic control.

Although the effect of the climatic zone on fertile tillering was significant, it accounted for only a small portion $(1 \%)$ of the variation for this trait. The lower percentage of fertile tillering recorded in landraces from northern zones (Z3 and Z4) when compared with the southern ones (Z1 and Z2) is consistent with previous results (Moragues et al. 2006). However, we did not detect a significant relationship between climatic traits in the area of origin of the landraces and fertile tillering.

As expected, the effect of the climatic zone on yield and yield components was much lower than the effects of year and genotype. The great number of tillers and spikes per unit area of landraces from the warmest and driest climatic zone (Z1), when compared with those of the other areas, did not compensate for their lighter grains, thus resulting in lower average yields. As yield components are developmentally interactive, lower tiller was further compensated by greater kernel weight. The greater tiller and spike number of landraces from $\mathrm{Z} 1$ could be related to the distinct yield formation strategies followed by durum wheat genotypes, which in turn are governed by the growing environment. Previous studies have demonstrated that durum wheat yield under warm and dry Mediterranean environments is determined mostly by the number of spikes per unit area, whereas kernel weight predominantly influences grain production in the cool and wet environments (García del Moral et al. 2003; Moragues et al. 2006; Royo et al. 2006). The significant and positive effect of the minimum temperatures during grain filling in the country of origin on the number of tillers and spikes per unit area and also the negative relationship found between $\mathrm{ET}_{0}$ during the same period and kernel weight are also in agreement with this statement.

Differences in kernel weight and grain filling rate were significant only between $\mathrm{Z} 1$ and the other zones; however, both traits tended to increase from $\mathrm{Z} 1$ to $\mathrm{Z} 4$. Moreover, our results indicate that landraces from areas with high $\mathrm{ET}_{0}$ during grain filling had a lower grain filling rate and lighter grains. This finding is consistent with the close relationship between grain weight and filling rate in durum wheat (Motzo et al. 1996), and the reduction in grain filling rate (Nicolas et al. 1985) and grain weight (Egli 1998; Royo et al. 2000) caused by drought in grain crops. The shorter grain filling duration of the landraces from northern areas was compensated by a higher rate, thus leading to heavier grains. This could be explained by the plants having greater opportunities to increase grain weight in colder and wetter areas than in the warmer and drier ones, which are subjected to terminal drought (Royo et al. 2000). The selection for heavier grains during the dispersal of durum wheat throughout the Mediterranean Basin that occurred in all domesticated cereals may also have contributed (Peng et al. 2011).

The data we obtained for the modern varieties used for comparison are in agreement with previous results from studies involving historical series of durum wheat cultivars. For many traits, such as cycle length, fertile tillering, number of spikes and grains per unit area, and grain filling rate, the values recorded in modern varieties were closer to those of landraces from $\mathrm{Z} 1$ than to those from the other zones, particularly the colder and wetter ones. These results suggest that breeding programs in the Mediterranean Basin resulted in the introgression of traits that, during centuries, ensured adaptation of durum wheat landraces to the warmer and drier areas within the region. However, the greater $\mathrm{HI}$ of the modern varieties and their superior number of grains per spike, a pleiotropic effect of major dwarfing genes (Álvaro et al. 2008), explain their greater yield, even under water limitation in our experimental conditions.

\section{Conclusions}

The countries origin of the landraces used in this study widely represent the climatic conditions of the main durum wheat-growing areas within the Mediterranean Basin. Identified through the multivariate analysis of long-term climatic data of the main wheat-growing areas in each country, the four climatic zones differed in climatic traits. However, the greatest differences appeared between southern (Z1 and Z2) and northern 
(Z3 and Z4) environments, which is consistent with the Koeppen's climate classification. High temperatures, solar radiation and $\mathrm{ET}_{0}$, all typical of warm environments, were associated with low rainfall and relative humidity, while cold environments were associated with more rainfall, especially during the spring.

Our results demonstrate that the climatic conditions of the zone in which the landraces were developed and to which they are highly adapted significantly affected their agronomic performance when cultivated in a random Mediterranean type-environment. The climate of the countries of origin had very large effects on cycle length, particularly on the number of days from sowing to heading and anthesis, which steadily increased when moving from the warmest and driest zone to the coldest and wettest one, thus causing the opposite effect on the duration of the grain filling period. The climate of the zone of origin of the landraces significantly affected biomass and yield formation, but its effect was high only for plant height and, to a lesser extent, for the grain filling rate. However, in most cases, the significant effect of the climatic zone was due to differences between landraces originated in southeastern Mediterranean countries (Z1), and those from the other three climatic zones. Thus, landraces originated in the warmest and driest area, corresponding to the southeastern Mediterranean countries (Israel, Libya, Jordan, Egypt and Syria) had less biomass, more grains per unit area, a lower grain filling rate, lighter grains, and lower yields than those that developed in other zones characterized by colder and wetter climatic conditions.

Solar radiation in the country in which the landraces were collected was the climatic variable most affecting (negatively) their cycle length, plant height, and biomass production, while minimum temperatures had the largest (positive) effect on the number of tillers and spikes per unit area. In addition, $\mathrm{ET}_{0}$ in the country of origin was the climatic variable most closely related to kernel weight and final grain yield, causing a detrimental effect on the expression of these agronomic traits.

Acknowledgments R. Nazco was recipient of a PhD Grant from the Comisionat per Universitats i Investigació del Departament d'Innovació, Universitats i Empresa of the Generalitat de Catalunya and the Fondo Social Europeo. This study was partially funded by CICYT under projects AGL200911187 and AGL-2012-37217. The Centre UdL-IRTA is part of the Centre CONSOLIDER INGENIO 2010 on Agrigenomics funded by the Spanish Ministry of Education and Science. Thanks are given to CRF-INIA, ICARDA and USDA Germplasm Bank for providing accessions for this study.

Open Access This article is distributed under the terms of the Creative Commons Attribution License which permits any use, distribution, and reproduction in any medium, provided the original author(s) and the source are credited.

\section{References}

Álvaro F, Isidro J, Villegas D, García del Moral LF, Royo C (2008) Old and modern durum wheat varieties from Italy and Spain differ in spike components. Field Crops Res 106:86-93

Angus JF, Mackenzie DH, Morton R, Schafer CA (1981) Phasic development in field crops: II. Thermal and photoperiodic responses of spring wheat. Field Crops Res 4:269-283

Annicchiarico P, Pecetti L, Damania AB (1995) Relationships between phenotypic variation and climatic factors at collecting sites in durum-wheat landraces. Hereditas 122:163-167

Araus JL, Slafer GA, Reynolds MP, Royo C (2002) Plant breeding and drought in $\mathrm{C}_{3}$ cereals: What should we breed for? Ann Bot 89:925-940

Blum A (2011) Plant breeding for water-limited environments. Springer, Berlin

Blum A, Pnuel Y (1990) Physiological attributes associated with drought resistance of 2 wheat cultivars in a Mediterranean environment. Aust J Agric Res 41:799-810

Chakrabarti B, Singh SD, Nagarajan S, Aggarwal PK (2011) Impact of temperature on phenology and pollen sterility of wheat varieties. Aust J Crop Sci 5:1039-1043

Charmet G (2011) Wheat domestication: lessons for the future. C R Biol 334:212-220

Cockram J, Norris C, O'Sullivan DM (2009) PCR-based markers diagnostic for spring and winter seasonal growth habit in barley. Crop Sci 49:403-410

Edmeades GO, Bolanos J, Lafitte HR, Rajaram S, Pfeiffer W, Fisher RA (1989) Traditional approaches to breeding for drought resistance in cereals. In: Baker FWG (ed) Drought resistance in cereals. ICSU Press, Wallingford, pp 27-52

Egli DB (1998) Seed biology and the yield of grain crops. CAB International, Oxford

FAOSTAT (2011) http://faostat.fao.org/site/368/DesktopDefault. aspx?PageID=368\#ancor/.Last. Accessed 25 Jan 2012

Fuller DQ (2007) Contrasting patterns in crop domestication and domestication rates: recent archaeobotanical insights from the Old World. Ann Bot 100:903-924

García del Moral LF, Rharrabti Y, Villegas D, Royo C (2003) Evaluation of grain yield and its components in durum wheat under Mediterranean conditions: an ontogenic approach. Agron J 95:266-274

Greco M, Mirauda D, Squicciarino G, Telesca V (2005) Desertification risk assessment in southern Mediterranean areas. Adv Geosci 2:243-247

Hammer K, Teklu Y (2008) Plant genetic resources: selected issues from genetic erosion to genetic engineering. J Agric Rural Dev Trop Subtrop 109:15-50 
Havaux M, Tardy F (1999) Loss of chlorophyll with limited reduction of photosynthesis as an adaptive response of Syrian barley landraces to high-light and heat stress. Aust J Plant Physiol 26:569-578

Hay RKM (1999) Physiological control of growth and yield in wheat: analysis and synthesis. In: Smith DL, Hamel C (eds) Crop yield, physiology and processes. Springer, Berlin, pp 1-38

International Wheat Council (2001) World production of durum wheat. The Council, London

Leemans R, Cramer W (1991) The IIASA database for mean monthly values of temperature, precipitation and cloudiness on a global terrestrial grid. International Institute of Applied Systems Analyses, Luxemburg, RR-91-18

Littell RC, Milliken GA, Stroup WW, Wolfinger RD (1996) SAS system for mixed models. SAS Institute Inc., Cary

MacKey J (2005) Wheat, its concept, evolution and taxonomy. In: Royo C, Nachit M, Di Fonzo N, Araus JL, Pfeiffer WH, Slafer GA (eds) Durum wheat breeding: current approaches and future strategies, vol 1. Haworth Press, New York, pp 3-62

Moragues M, García del Moral LF, Moralejo M, Royo C (2006) Yield formation strategies of durum wheat landraces with distinct pattern of dispersal within the Mediterranean basin: I. Yield components. Field Crops Res 95:194-205

Moragues M, Moralejo M, Sorrells ME, Royo C (2007) Dispersal of durum wheat landraces across the Mediterranean basin assessed by AFLPs and microsatellites. Genet Resour Crop Evol 54:1133-1144

Motzo R, Giunta F, Deidda M (1996) Relationships between grain-filling parameters, fertility, earliness and grain protein of durum wheat in a Mediterranean environment. Field Crops Res 47:129-142

Nazco R, Villegas D, Ammar K, Peña RJ, Moragues M, Royo C (2012) Can Mediterranean durum wheat landraces contribute to improved grain quality attributes in modern cultivars? Euphytica 185(1):1-17. doi:10.1007/s10681011-0588-6

Nazco R, Peña RJ, Ammar K, Villegas D, Crossa J, Moragues M, Royo C (2013) Variability in glutenin subunit composition of Mediterranean durum wheat germplasm and its relationship with gluten strength. J Cereal Sci. doi:10.1017/ S0021859613000117

Nazco R, Peña RJ, Ammar K, Villegas D, Crossa J, Royo C (2014) Durum wheat Mediterranean landraces as sources of variability for allelic combinations at Glu-1/Glu-3 loci affecting gluten strength and pasta cooking quality. Genet Resour Crop Evol. doi:10.1007/s10722-014-0104-7

Nicault A, Alleaume S, Brewer S, Carrer M, Nola P, Guiot J (2008) Mediterranean drought fluctuation during the last 500 years based on tree-ring data. Clim Dyn 31:227-245

Nicolas ME, Gleadow RM, Dalling MH (1985) Effect of postanthesis drought on cell division and starch accumulation in developing wheat grains. Ann Bot 55:433-444

Palamarchuk A (2005) Selection strategies for traits relevant for winter and facultative durum wheat. In: Royo C, Nachit
MM, Di Fonzo N, Araus JL, Pfeiffer WH, Slafer GA (eds) Durum wheat breeding. Current approaches and future strategies, vol 2. Haworth Press, New York, pp 599-644

Peng JH, Sun D, Nevo E (2011) Domestication evolution, genetics and genomics in wheat. Mol Breed 28:281-301

Richards RA (2000) Selectable traits to increase crop photosynthesis and yield of grain crops. J Exp Bot 51:447-458

Royo C, Abaza M, Blanco R, García del Moral LF (2000) Triticale grain growth and morphometry as affected by drought stress, late sowing and simulated drought stress. Aust J Plant Physiol 27:1051-1059

Royo C, Aparicio N, Blanco R, Villegas D (2004) Leaf and green area development of durum wheat genotypes grown under Mediterranean conditions. Eur J Agron 20:419-430

Royo C, Villegas D, Rharrabti Y, Blanco R, Martos V, García del Moral LF (2006) Grain growth and yield formation of durum wheat grown at contrasting latitudes and water regimes in a Mediterranean environment. Cereal Res Commun 34:1021-1028

Santiveri F, Royo C, Romagosa I (2002) Patterns of grain filling of spring and winter hexaploid triticales. Eur $\mathrm{J}$ Agron 16:219-230

SAS Institute Inc. (2009) SAS/STAT ${ }^{\circledR}$ 9.2. User's guide, 2nd edn. SAS Institute Inc., Cary

Tanno K, Willcox G (2006) How fast was wild wheat domesticated? Science 311:1886

Tewolde H, Fernandez CJ, Erickson CA (2006) Wheat cultivars adapted to postheading high temperatures. J Agron Crop Sci 192:111-120

Trigo RM, Gouveia CM, Barriopedro D (2010) The intense 2007-2009 drought in the Fertile Crescent: impacts and associated atmospheric circulation. Agric For Meteorol 150:1245-1257

Villegas D, Aparicio N, Blanco R, Royo C (2001) Biomass accumulation and main stem elongation of durum wheat grown under Mediterranean conditions. Ann Bot 88: $617-627$

Wiegand CL, Cuellar JA (1981) Duration of grain filling and kernel weight of wheat as affected by temperature. Crop Sci 21:95-101

Xianshan W, Zhenghang W, Xiaoping C, Ruilian J (2010) Genetic dissection of the developmental behaviours of plant height in wheat under diverse water regimes. J Exp Bot 61:2923-2937

Xoplaki E, Gonzalez-Rouco JF, Luterbacher J, Wanner H (2004) Wet season Mediterranean precipitation variability: influence of large-scale dynamics and trends. Clim Dyn 23:63-78

Zadoks JC, Chang TT, Konzak CF (1974) A decimal code for the growth stage of cereals. Weeds Res 14:415-421

Zeven AC (1998) Landraces: a review of definitions and classifications. Euphytica 104:127-139

Zohary D, Hopf M (2000) Domestication of plants in the Old World. Oxford University Press, Oxford 